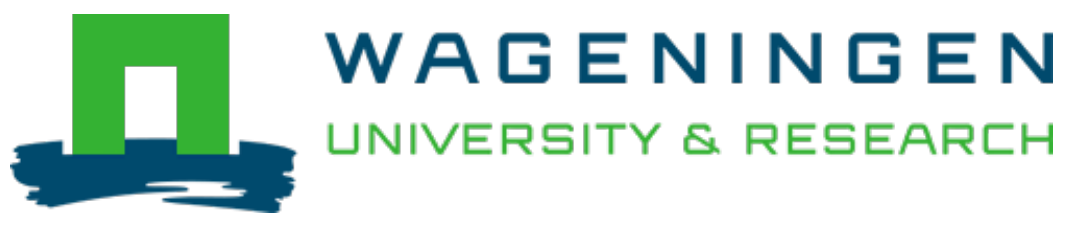

\title{
Tempeh as a functional food
}

Soybeans as functional foods and ingredients

Nout, M.J.R.; Kiers, J.L.

This publication is made publicly available in the institutional repository of Wageningen University and Research, under the terms of article $25 \mathrm{fa}$ of the Dutch Copyright Act, also known as the Amendment Taverne. This has been done with explicit consent by the author.

Article 25 fa states that the author of a short scientific work funded either wholly or partially by Dutch public funds is entitled to make that work publicly available for no consideration following a reasonable period of time after the work was first published, provided that clear reference is made to the source of the first publication of the work.

This publication is distributed under The Association of Universities in the Netherlands (VSNU) 'Article $25 \mathrm{fa}$ implementation' project. In this project research outputs of researchers employed by Dutch Universities that comply with the legal requirements of Article $25 \mathrm{fa}$ of the Dutch Copyright Act are distributed online and free of cost or other barriers in institutional repositories. Research outputs are distributed six months after their first online publication in the original published version and with proper attribution to the source of the original publication.

You are permitted to download and use the publication for personal purposes. All rights remain with the author(s) and / or copyright owner(s) of this work. Any use of the publication or parts of it other than authorised under article $25 \mathrm{fa}$ of the Dutch Copyright act is prohibited. Wageningen University \& Research and the author(s) of this publication shall not be held responsible or liable for any damages resulting from your (re)use of this publication.

For questions regarding the public availability of this publication please contact openscience.library@wur.nl 


\section{Soybeans as Functional Foods and Ingredients}

Editor

KeShun Liu, Ph.D.

University of Missouri

Columbia, Missouri

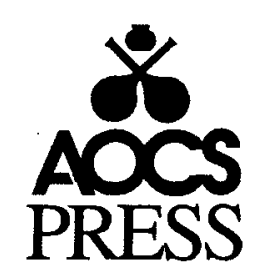

Champaign, Illinois 


\title{
Chapter 12
}

\section{Tempeh as a Functional Food}

\author{
M.J.R. Nout and J.L. Kiers \\ Wageningen University, Wageningen, The Netherlands, and Friesland Coberco Dairy Foods, \\ Leeuwarden, The Netherlands
}

Tempeh is a fungal fermented soybean food originating from Indonesia but increasingly known internationally. It is produced by a process involving dehulling, soaking, cooking, and fermenting soybeans by fungal solid-state fermentation. The fungal enzyme activity causes significant decomposition of polymeric components, as well as a considerable modification of soybean flavonoids. As a result, tempeh offers a number of proven health benefits including excellent digestibility and protection against diarrhea and chronic degenerative diseases. Tempeh also gains importance as an interesting food-grade ingredient for formulated functional foods.

\section{Production of Tempeh}

Tempeh (also spelled "tempe") is a collective name for a sliceable mass of precooked fungal fermented beans, cereals, or some other by-products of food processing bound together by the mycelium of a living mold (mostly Rhizopus spp.). Yellow-seeded soybeans are the most common and preferred raw material used to make tempeh $(1-4)$. Figure 12.1 shows a cross section of soybean tempeh, as sold in the Netherlands.

The process of tempeh manufacture is shown in Figure 12.2. Tempeh making involves dehulling of soybeans (the most common starting material), soaking in

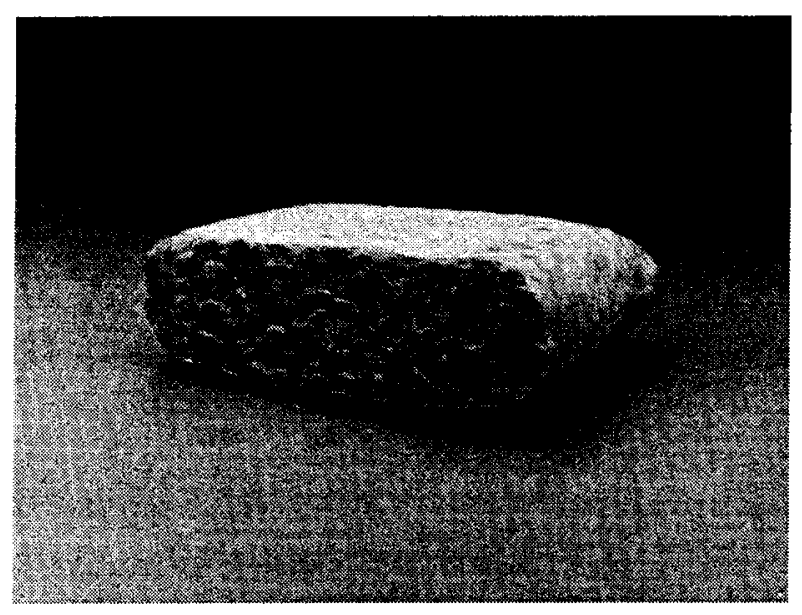

Figure 12.1. Cross section of tempeh showing the fungal mycelium penetrating the mass of soybeans. 


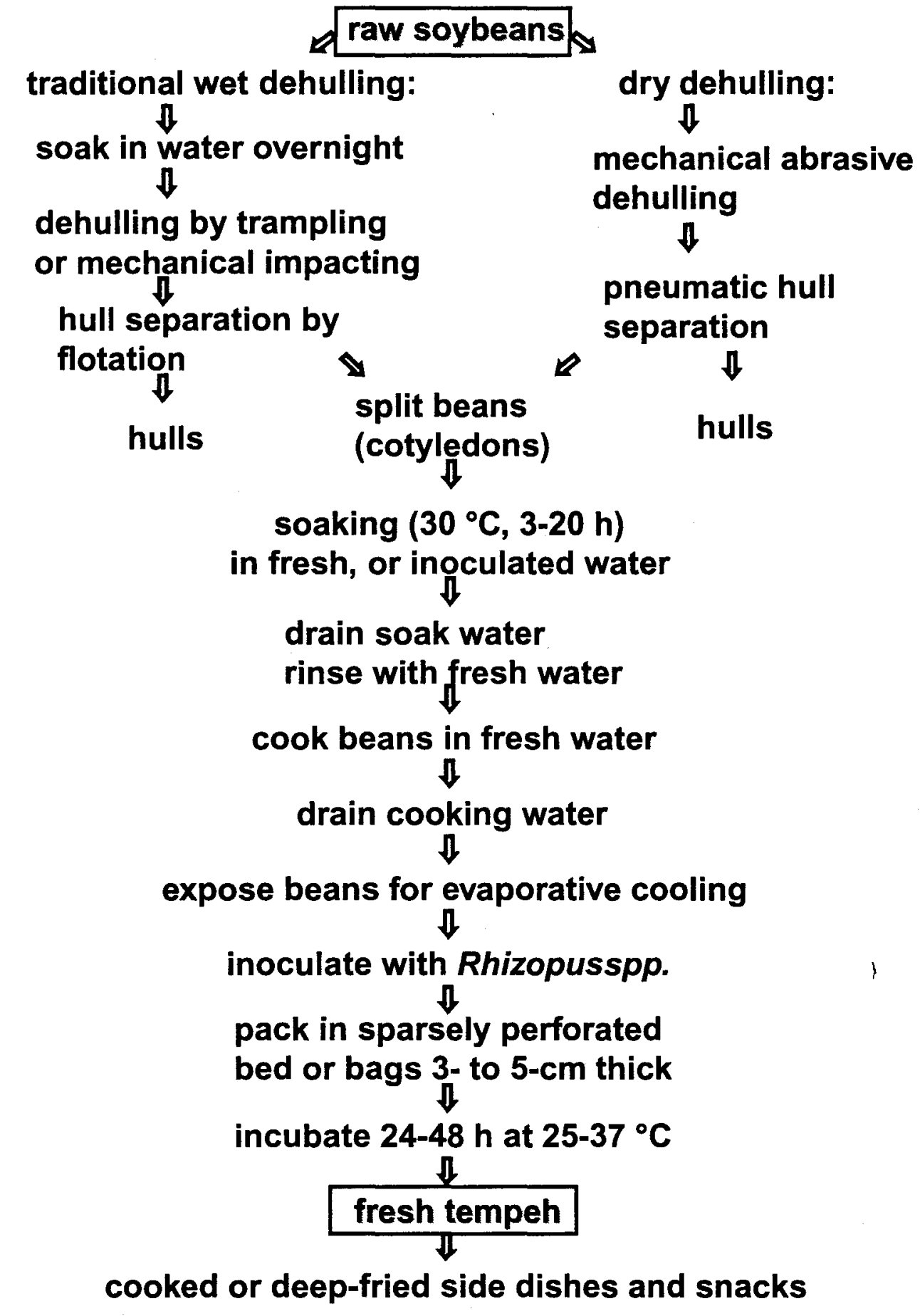

Figure 12.2. Simplified process diagram of tempeh manufacture.

water, boiling in fresh water, inoculation with fermentation starter, and solid-state fermentation of beds of inoculated beans. After incubation periods of typically 2 days at $30^{\circ} \mathrm{C}$, fresh tempeh can be harvested and processed into meal components, snacks, or dehydrated to obtain powdered protein enrichment.

A wide variety of microorganisms is involved in the fermentation step of tempeh production. During the soaking stage, bacterial activity is fueled by the water-soluble matter leaching from the beans. During the solid-state fermenta- 
tion, molds (especially Rhizopus oligosporus, $R$. oryzae, and Mucor indicus) are responsible for texture and flavor, but most importantly for the enzyme activities that are expressed. Important enzymes include carbohydrases (5) degrading fiber, proteases (6), and lipases (7). As a result of these enzymatic activities, the cooked beans undergo significant biochemical modifications, which improve the taste and flavor, as well as the functional properties of the product (Table 12.1). With its high protein content (40-50\% of dry matter) it serves as a tasty protein complement to starchy staple foods such as rice, and it can replace meat or fish in the diet. In Indonesia, the estimated consumption ranges from 19-34 grams per day per person (8). Tempeh is not consumed raw, but is heated first to develop meatlike flavors, for example, by frying spiced and salted slices in oil, by boiling with coconut milk in soups, by stewing, by roasting spiced kebobs, and by grinding into peppered ground pastes.

\section{Functional Properties}

\section{History of Use}

Tempeh has evolved as a traditional meat alternative in Indonesia. It was locally known for its easy digestibility, and there is anecdotal evidence that during World War II, prisoners of war suffering from dysentery could not tolerate soybeans but were able to subsist on tempeh; this underscores the easy digestibility of tempeh. During the 1960s, tempeh turned global and became a favorite of vegetarians. Nowadays, increasing numbers of nonvegetarian consumers include it in the diet for the purpose of variation and to reduce the number of "meat-days." Local experience

\section{TABLE 12.1}

Nutrient Comparison of Tempeh and Chicken Egg and Vitamin Synthesis in Tempeh during Its Fermentation

\begin{tabular}{lcc}
\hline Composition (\% product) & Tempeh & Chicken Egg \\
\hline dry matter & $34-40$ & 25 \\
(\% dry matter basis) & 53 & 52 \\
Crude protein & 20 & 44 \\
Crude lipid & 8.6 & - \\
Crude fiber & - & 0.6 \\
cholesterol & 18.9 & 25.6 \\
Energy, MJ/kg & Cooked soybeans & Tempeh \\
& 1.5 ppm & $6.5 \mathrm{ppm}(\times 4.4)$ \\
\hline Riboflavin (vitamin $\mathrm{B}_{2}$ ) & 6.7 & $25.2(\times 3.8)$ \\
Nicotinic acid & 1.8 & $8.3(\times 4.6)$ \\
Pyridoxine $\left(\mathrm{B}_{6}\right)$ & 0.25 & $1.0(\times 4.0)$ \\
Folic acid & & \\
\hline
\end{tabular}


in Indonesia shows that addition of tempeh to the diet of (young) diarrhea patients shortens the recovery period (9) after the disease.

\section{Predigestion of Nutrients}

The easy digestibility of tempeh is related to the enzymatic degradation of soybean polymeric substances resulting in soluble solids, such as soluble nitrogenous compounds. Macromolecules are degraded into oligomeric and smaller units, which improves tempeh digestion (10). Digestibility of cereals and legumes increases during cooking, and continues to increase during fermentation (11). Cooking improved the total in vitro digestibility of both soybean (from $37 \%$ to $45 \%$ ) and cowpea (from $15 \%$ to $41 \%$ ). Subsequent fungal fermentation increased total digestibility only about 3\% for both soybean and cowpea. Digestibility was influenced by fungal strain and fermentation time. Although total digestibility of cooked legumes was only slightly improved by mold fermentation, the level of nonfat water-soluble dry matter of food samples increased spectacularly from $4 \%$ up to $17 \%$ for soybean and from $4 \%$ up to $24 \%$ for cowpea (Table 12.2). This illustrates that mold fermentation already "predigests" the soybean macronutrients to a significant extent. Fermentation was nearly capable of increasing nutrient availability to the level obtained after in vitro digestion of cooked soybeans. In vivo trials with rats and piglets show evidence of increased protein digestibility, increased protein efficiency ratio and net protein utilization (12), and higher uptake of total solutes (13).

\section{Antimicrobial Effects}

Tempeh was reported to contain an antibacterial substance, confirmed by demonstrated antimicrobial activity against selected species of Gram-positive bacteria (14-16). Recent work shows that several tempeh extracts were able to inhibit adhesion of $E$. coli to piglet small intestinal brush border membranes in vitro (Fig. 12.3) and might therefore have a protective effect against $E$. coli infection (16).

\section{TABLE 12.2}

Changes in In Vitro Absorbability and Digestibility as a Result of Tempeh Fermentation (11)

\begin{tabular}{lccc}
\hline & $\begin{array}{c}\text { Absorbability } \\
\text { (\% of fat-free dm) }\end{array}$ & $\begin{array}{c}\text { Digestibility } \\
\text { (\% of fat-free dm) }\end{array}$ & $\begin{array}{c}\text { ND } \\
(\%)\end{array}$ \\
\hline $\begin{array}{c}\text { Cooked soybean } \\
\text { Mold strain 575, }\end{array}$ & 4.8 & 22.3 & 22 \\
24 h fermented & 6.1 & 23.7 & 64 \\
$\begin{array}{c}\text { Mold strain 575, } \\
\text { 44h fermented }\end{array}$ & 16.7 & 26.1 & 64 \\
$\begin{array}{c}\text { Mold strain 582, } \\
\text { 24h fermented }\end{array}$ & 16.4 & 26.2 & 63 \\
$\begin{array}{c}\text { Mold strain 582, } \\
\text { 44h fermented }\end{array}$ & 14.0 & 27.2 & 51 \\
\hline
\end{tabular}




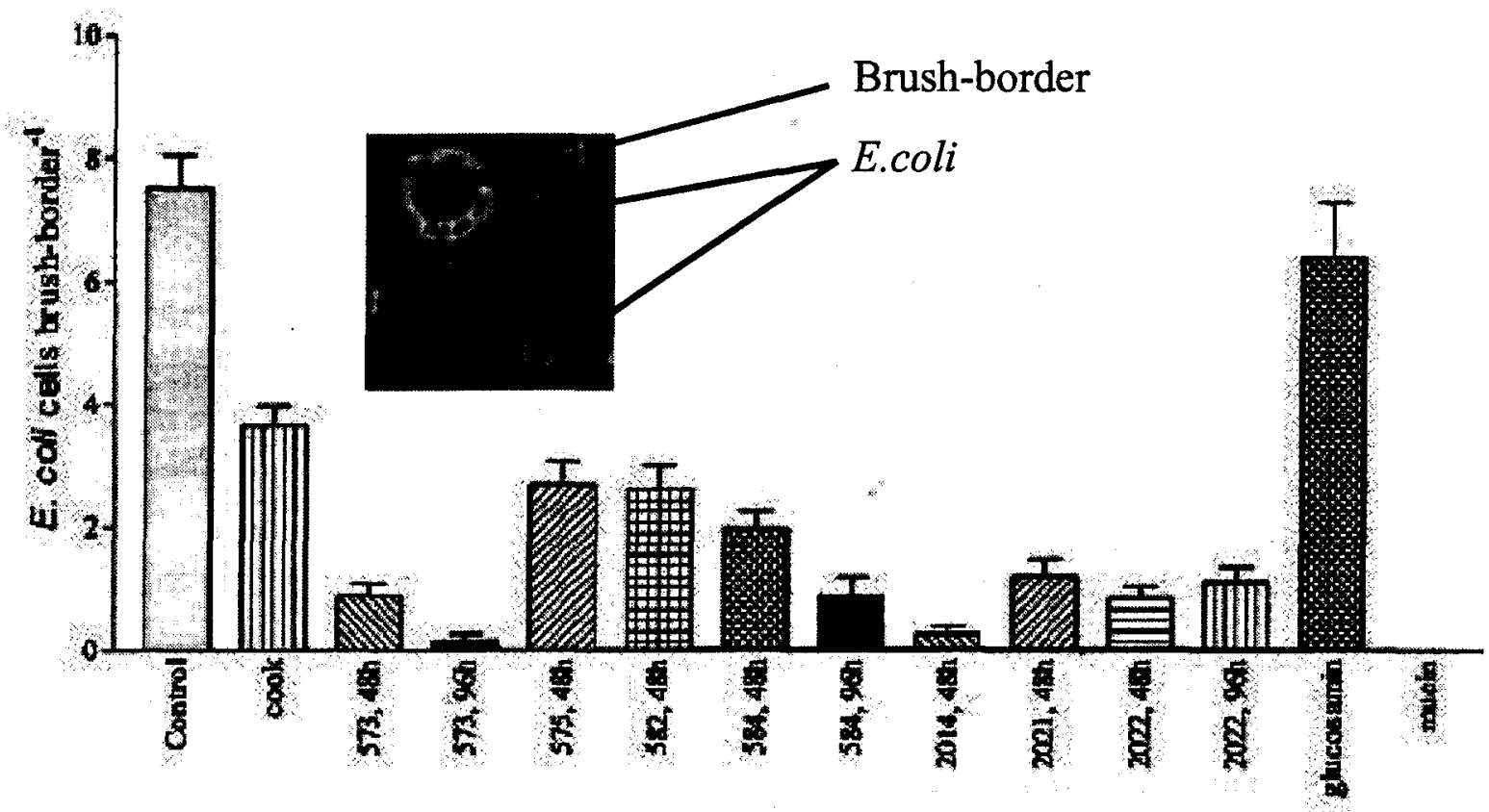

Figure 12.3. In vitro inhibition of adhesion of enterotoxigenic Escherichia coli to intestinal brush border membranes (16).

\section{Protection against Diarrhea}

In rabbits and piglets, diarrhea caused by $E$. coli was reduced by tempeh. These findings correlate with a protective effect against fluid losses found in small intestinal segment perfusion experiments (13) in piglets. Tempeh appeared to contain a highmolecular-weight fraction $(>5 \mathrm{kDa}$ ) that protected against fluid losses induced by ETEC. Tempeh can be very useful as a nutritional supplement in oral rehydration therapy, and in cases of (post-weaning) diarrhea, for accelerating the recovery of young animals and young children, who are most at risk for enterotoxic diarrhea and malnutrition. The effect on the occurrence and severity of diarrhea in ETEC K88+-challenged weaned piglets was determined by Kiers et al. (17). Severity of diarrhea was significantly less on the diet containing tempeh compared with the control diet containing toasted soybeans. Various beneficial effects of tempeh in disease prevention and treatment, principally in diarrhea management, and positive nutritional impact in Indonesian children have been reported (18-20). An immune modulating effect was suggested, but further evidence for this phenomenon will have to be sought (21).

\section{Intestinal Growth and Proliferation}

Weaning is often associated with marked histological and biochemical changes of the small intestine, causing decreased digestive and absorptive capacity and contributing to post-weaning diarrhea. Biopsies from the human small intestinal mucosa showed improved repair after intestinal inflammation as a result of tempeh supplementation (9). In a trial with piglets, no indication of beneficial effects of tempeh on 
maintaining or quickly restoring villous height in piglets after weaning was observed (J.L. Kiers et al., unpublished data).

\section{Antioxidative Properties of Fermented Soybeans}

Soybeans contain natural antioxidants. It is interesting to note that fermented soyfoods do not lose their antioxidative properties, but in contrast show increased antioxidative capacity (22). The four important aglycones in tempeh are genistein, daidzein, glycitein, and factor 2 (6,7,4'-trihydroxyisoflavone) (23). Another antioxidative substance in tempeh was identified as 3-hydroxyanthranilic acid (HAA); this was not detected in unfermented beans (24) and was formed only as a result of fungal fermentation. Of several soybean foods, tempeh had somewhat lower isoflavone content than tofu but contained elevated levels of the aglycones formed by enzymatic hydrolysis during fermentation $(25,26)$. Fermentation of soy increased the human bioavailability of isoflavones. This was shown in vivo: eight women aged 20-41 years retained approximately $75 \%$ of isoflavones (daidzein and genistein) from soyfoods including tempeh (27).

\section{Chronic Degenerative Diseases}

Besides the role of antioxidants in protecting foods against oxidative spoilage, antioxidants in soybeans (and tempeh) are of interest with respect to their protective role against oxidative stress known to be involved in the pathogenesis of various chronic degenerative diseases such as cancer; coronary diseases, osteoporosis, and menopausal symptoms. Soybean protein has been known for many years to have a hypocholesterolemic effect. It is therefore not surprising that tempeh has also been found to lower blood cholesterol levels (28) and may therefore be of benefit as a protective agent against cardiovascular disease. In a number of clinical intervention trials, total cholesterol and low-density lipoprotein (LDL) cholesterol were significantly reduced in subjects treated with tempeh, whereas high-density lipoprotein (HDL) cholesterol was raised $(19,29,30)$. It was demonstrated that tempeh, especially its glucolipids, inhibits the proliferation of tumour cells in mice $(31,32)$. In Southeast Asia, Indonesians are undoubdtedly the largest consumers of tempeh, as well as of tofu (locally called tahu). Epidemiological studies relating to tempeh consumption and the prevalence of cancer, particularly in Indonesia, have not yet been conducted.

\section{Novel Applications}

In addition to its traditional use in both Oriental and Western cuisine, tempeh can be processed into powdered form for convenient use in formulated foods and feeds. The use of tempeh in the rehabilitation of children suffering from protein-energy malnutrition in Indonesia was shown to have a greater nutritional impact than food mixtures containing cooked but unfermented soybeans. Protein-energy malnutrition is highly prevalent in developing countries due to the decline in breast-feeding, use of complementary foods that are low in energy and nutrients, and a high prevalence of diarrhea and infections (33). Fermentation of soybean-cereal mixtures has great potential for application in comple- 
mentary foods. Because of their nutritional relevance, mixtures of cereals and leguminous seeds, such as finger millet with various legumes (34), maize and soybean, rice and black beans (35), and sorghum and common bean have been evaluated. The nutritional potential and superior digestibility make tempeh a valuable enrichment for starch-based formulated foods, such as infant porridges (36), among others. A significantly higher growth rate, shorter duration of diarrheal episodes, and shorter rehabilitation period was reported in children suffering from protein-energy malnutrition who were given a porridge containing tempeh and yellow maize, compared to those fed a similar porridge made of milk and yellow maize (37). Functional properties of tempeh will be of interest in the areas of diarrhea management, nutritional recovery of compromised patients, and health foods (38), as well as in specialized feeds such as weaning formula for piglets.

\section{References}

1. Ko, S.D., and C.W. Hesseltine, Tempe and Related Foods, in Microbial Biomass, edited by A.H. Rose, Academic Press, London, 1979, Vol. 4, pp. 115-140.

2. Nout, M.J.R., and F.M. Rombouts, Recent Developments in Tempe Research, J. Appl. Bacteriol. 69:609-633 (1990).

3. Steinkraus, K.H., Handbook of Indigenous Fermented Foods (2nd ed.), Marcel Dekker, New York, 1995.

4. Nout, M.J.R., and J.L. Kiers, Tempe Fermentation, Innovation and Functionality: Up-date into the 3rd Millenium, J. Appl. Microbiol., in press.

5. Sarrette, M., M.J.R. Nout, P. Gervais, and F.M. Rombouts, Effect of Water Activity on Production and Activity of Rhizopus oligosporus Polysaccharidases, Appl. Microbiol. Biotechnol. 37:420-425 (1992).

6. Baumann, U., and B. Bisping, Proteolysis during Tempe Fermentation, Food Microbiol. 12:39-47 (1995).

7. Ruiz-Teran, F., and J.D. Owens, Chemical and Enzymic Changes during the Fermentation of Bacteria-Free Soya Bean Tempe, J. Sci. Food Agric. 71:523-530 (1996).

8. Sayogyo, S., Tempe in the Indonesian Diet (abstract), in Second Asian Symposium on Non-salted Soybean Fermentation, edited by H. Hermana, M.K.M.S. Mahmud, and D. Karyadi, Nutrition Research and Development Centre, Jakarta, Indonesia, 1990, p. 17

9. Sudigbia, I., Tempe in the Management of Infant Diarrhea in Indonesia, in The Complete Handbook of Tempe, edited by J. Agranoff, American Soybean Association, Singapore, 1999, pp. 33-40.

10. Matsuo, M., Digestibility of Okara-Tempe Protein in Rats, J. Jpn. Soc. Food Sci. Technol. [Nippon Shokuhin Kagaku Kogaku Kaishi] 43:1059-1062 (1996).

11. Kiers, J.L., M.J.R. Nout, and F.M. Rombouts, In Vitro Digestibility of Processed and Fermented Soya Bean, Cowpea and Maize, J. Sci. Food Agric. 80:1325-1331 (2000).

12. Tchango, J.T., The Nutritive Quality of Maize-Soybean (70:30) Tempe Flour, Plant Foods Hum. Nutr. 47:319-326 (1995).

13. Kiers, J.L., M.J.R. Nout, F.M. Rombouts, M.J.A. Nabuurs, and J. Van der Meulen, Protective Effect of Processed Soya Bean during Perfusion of ETEC-Infected Small Intestinal Segments of Early-Weaned Piglets, in 8th Symposium on Digestive Physiology in Pigs, Uppsala, Sweden, 2000.

14. Rachmaniar, R., and E. Siregar, A Preliminary Study on the Chemical Composition of Tempe Extract as an Antimicrobial Activity (abstract), in Second Asian Symposium on 
Non-salted Soybean Fermentation, edited by H. Hermana, M.K.M.S. Mahmud, and D. Karyadi, Nutrition Research and Development Centre, Jakarta, Indonesia, 1990, p.10.

15. Kobayasi, S.Y., N. Okazaki, and T. Koseki, T., Purification and Characterization of an Antibiotic Substance Produced from Rhizopus oligosporus IFO 8631, Biosci. Biotechnol. Biochem. 56:94-98 (1992).

16. Kiers, J. L., M.J.R. Nout, F.M. Rombouts, M.J.A. Nabuurs, and J. Van der Meulen, Inhibition of Adhesion of Enterotoxic Escherichia coli $\mathrm{K} 88$ by Soya Bean Tempe, Lett. Appl. Microbiol. 35:311-315 (2002).

17. Kiers, J.L., J.C. Meijer, M.J.R. Nout; F.M. Rombouts, M.J.A. Nabuurs, and J. Van der Meulen, Effect of Fermented Soya Beans on Diarrhea and Feed Efficiency in Weaned Piglets, J. Appl. Microbiol. 95:545-552 (2003).

18. Soenarto, Y., I. Sudigbia, H. Hermana, M. Karmini, and D. Karyadi, Antidiarrheal Characteristics of Tempe Produced Traditionally and Industrially in Children Aged 6-24 Months with Acute Diarrhea, in International Tempe Synposium, edited by S. Sudarmadji, S. Suparmo, and S. Raharjo, Indonesian Tempe Foundation, Jakarta, Indonesia, Bali, Indonesia, 1997, pp. 174-186.

19. Karyadi, D., and W. Lukito, Beneficial Effects of Tempeh in Disease Prevention and Treatment, Nutr. Rev. 54:S94-S98 (1996).

20. Karyadi, D., and W. Lukito, Functional Food and Contemporary Nutrition-Health Paradigm: Tempeh and Its Potential Beneficial Effects in Disease Prevention and Treatment, Nutrition 16:697 (2000).

21. Karmini, M., Tempe and Infection, in The Complete Handbook of Tempe, edited by J. Agranoff, American Soybean Association, Singapore, 1999, pp. 46-50.

22. Berghofer, E., B. Grzeskowiak, N. Mundigler, W.B. Sentall, and J. Walcak, Antioxidative Properties of Faba Bean-, Soybean- and Oat Tempeh, Int. J. Food Sci. Nutr. 49:45-54 (1998).

23. Hoppe, M.B., H.C. Jha, and H. Egge, Structure of an Antioxidant from Fermented Soybeans (Tempeh), J. Am. Oil Chem. Soc. 74:477-479 (1997).

24. Esaki, H., H. Onozaki, S. Kawakishi, and T. Osawa, New Antioxidant Isolated from Tempeh, J. Agric. Food Chem. 44:696-700 (1996).

25. Anderson, R.L., and W.J. Wolf, Compositional Changes in Trypsin Inhibitors, Phytic Acid, Saponins and Isoflavones Related to Soybean Processing, J. Nutr. 125:S581-S588 (1995).

26. Wang, H.J., and P.A. Murphy, Mass Balance Study of Isoflavones during Soybean Processing, J. Agric. Food Chem. 44:2377-2383 (1996).

27. Xu, X., H.J. Wang, P.A. Murphy, and S. Hendrich, Neither Background Diet nor Type of Soy Food Affects Short-Term Isoflavone Bioavailability in Women, J. Nutr. 130:798-801 (2000).

28. Guermani, L., C. Villaume, H.M. Bau, J.P. Nicolas, and L. Mejean, Modification of Soyprotein Hypocholesterolemic Effect after Fermentation by Rhizopus oligosporus spT3, Sciences des Aliments 13:317-324 (1993).

29. Brata-Arbai, A.M., The Effect of Tempe Diet on Uric Acid and Plasma Lipid Level, in International Tempe Symposium, Den Pasar, Bali, Indonesia, Indonesian Tempe Foundation, Jakarta, Indonesia, 1997, pp. 187-198.

30. Brata-Arbai, A.M., Cholesterol Lowering Effect of Tempe, in The Complete Handbook of Tempe, edited by J. Agranoff, American Soybean Association, Singapore, 1999, pp. 51-70. 
31. Kiriakidis, S., S. Stathi, H.C. Jha, R. Hartmann, and H. Egge, Fatty Acid Esters of Sitosterol 3 Beta Glucoside from Soybeans and Tempe (Fermented Soybeans) as Antiproliferative Substances, J. Clin. Biochem. Nutr. 22:139-147 (1997).

32. Jha, H.C., S. Kiriakidis, M. Hoppe, and H. Egge, Antioxidative Constituents of Tempe, in International Tempe Symposium, Den Pasar, Bali, Indonesia, Indonesian Tempe Foundation, Jakarta, Indonesia, 1997, pp. 73-84.

33. Abiodun, P.O., Use of Soya-beans for the Dietary Prevention and Management of Malnutrition in Nigeria, Acta Paediatr. Scand. Suppl. 374:175-182 (1991).

34. Mugula, J.K., and M. Lyimo, Evaluation of the Nutritional Quality and Acceptability of Fingermillet-Based Tempe as Potential Weaning Foods in Tanzania, Int. J. Food Sci. Nutr. 50:275-282 (1999).

35. Rodriguez-Burger, A.P., A. Mason, and S.S. Nielsen, Use of Fermented Black Beans Combined with Rice to Develop a Nutritious Weaning Food, J. Agric. Food Chem. 46:4806-4813 (1998).

36. Kodyat, B.A., A. Sukaton, and D. Latief, Traditional Soybean Fermentation (Tempe) for Increasing Nutritional Status of Children in Indonesia, in Second Asian Symposium on Non-salted Soybean Fermentation, edited by H. Hermana, M.K.M.S. Mahmud, and D. Karyadi, Nutrition Research and Development Centre, Bogor, Indonesia, 1990, pp. 110-115.

37. Kalavi, F.N.M., N.M. Muroki, A.M. Omwega, and R.K.N. Mwadime, Effect of Tempe Yellow Maize Porridge and Milk Yellow Maize Porridge on Growth Rate, Diarrhoea and Duration of Rehabilitation of Malnourished Children, East African Med. J. 73:427-431 (1996).

38. Kiers, J.L., M.J.R. Nout, F.M. Rombouts, B.C. Koops, K.M.J. Van Laere, E. Wissing, R.J.J. Hagemann, and J. Van der Meulen, Process for the Manufacture of a Fermented Health-Promoting Product, European Patent Application No. 01201510.3-2110, Numico Nutrica, October 31, 2001. 